Østnor, T., Faanes, S., and Lædre, O. (2018). "Laminated timber versus on-site cast concrete: a comparative study." In: Proc. $26^{\text {th }}$ Annual Conference of the International. Group for Lean Construction (IGLC), González, V.A. (ed.), Chennai, India, pp. 1302-1312. DOI: doi.org/10.24928/2018/0313. Available at: www.iglc.net

\title{
LAMINATED TIMBER VERSUS ON-SITE CAST CONCRETE: A COMPARATIVE STUDY
}

\author{
Torstein Østnor ${ }^{1}$, Sigbjørn Faanes ${ }^{2}$, and Ola Lædre ${ }^{3}$
}

\begin{abstract}
Laminated timber is a relatively new construction material for multi-story buildings. With this type of structural engineered wood product, timber is glue laminated to increase its constructive strength. Laminated timber represents an opportunity to lower GHG emissions, while traditional on-site cast concrete is believed to be cheaper. The study examines differences between construction in laminated timber and cast concrete, and pros and cons associated with construction in laminated timber. The study began with a literature review. Then the construction of two neighboring apartment buildings that used Last Planner during both design and construction were studied. Takt planning was used in the production planning. Twelve interviews represent the main source of data and was supplemented with a study of documents and direct observations in design meetings. Use of laminated timber requires more resources in the design phase compared with the use of cast concrete. Fire and acoustic regulations, in particular, demand new construction guidelines. However, use of laminated timber saves time and provides a cleaner working environment during construction. Under the right circumstances, laminated timber appears to outperform on-site cast concrete. This study suggests Lean measures for contractors that want to benefit from the advantages of laminated timber and improve such construction.
\end{abstract}

\section{KEYWORDS}

Cross Laminated Timber, Cast Concrete, Last Planner, Takt, Prefabrication

\section{INTRODUCTION}

The fifth assessment report (IPCC 2014) of the Intergovernmental Panel on Climate Change confirms with $95 \%$ certainty that global warming is caused by anthropogenic greenhouse gas emissions. It is estimated that $18 \%$ of the global $\mathrm{CO}_{2}$ emissions are directly or indirectly generated by the building sector and is projected to increase by 50 -

1 Student M.Sc. Civil Engineering., Norwegian University of Science and Technology, Trondheim, Norway, +4795859 145, E-mail: torstein.ostnor@ veidekke.no

2 Project Developer/ Design Manager, Veidekke Entreprenør Trøndelag, Trondheim, Norway, E-mail: sigbjorn.faanes@ veidekke.no

3 Associate Professor, Dr. Ing., Norwegian University of Science and Technology, Trondheim, Norway, +47 91189 938, E-mail: ola.ladre@ntnu.no 
$150 \%$ by mid-century. These data highlight the need for greener materials and construction methods.

Life cycle assessments (LCAs) of the load bearing structures in mass timber and concrete buildings show that the $\mathrm{CO}_{2}$ emissions from timber structures can be $34-84 \%$ lower than from concrete structures (Skullestad et al. 2016). A weakness in LCAs from Scandinavia is the lack of life cycle cost analyses (Petersen and Solberg 2005). Builder experience with mass timber is limited and not widely known.

Veidekke AS, one of the largest contractors in Scandinavia, has a strategy to acquire knowledge on and gain a competitive advantage by building environmentally friendly buildings. Veidekke was using both mass timber and on-site cast concrete to construct two apartment buildings at the same building site in Trondheim, Norway, in a comparable setting. The contractor used the Lean method Collaborative Planning (CP), a Last Planner adaption, during design and construction. They also used Takt Planning for the construction planning. This provided a unique opportunity to research both on Lean construction and buildings in mass timber. The objective of this study was to investigate how Lean measures like Last Planner and Takt influence the construction process when new and green materials are introduced. To answer this objective, the following three research questions were formulated:

- What are the differences between construction in cross laminated timber (CLT) and on-site cast concrete?

- What pros and cons are associated with the use of CLT?

- How can contractors improve construction with CLT?

This paper provides a short disussion of mass timber along with an introduction to the Lean methods used in the case project. Then it presents the results of the case study. These results form the basis for improvement measures for those who want to benefit from the advantages mass timber can provide.

This study was limited by the progress of the project. In the spring of 2018, the construction phase barely had begun. The scope of this paper is for that reason limited to the concept development and detailed design phase.

\section{THEORETICAL BACKGROUND}

Mass timber is a common denomination of timber elements used for loadbearing purposes, mostly in buildings (Smith et al. 2017). Mass timber elements can be assembled in several different ways, both glued and non-glued. Cross laminated timber (CLT) was found to be most cost-effective alternative considering price, durability and strength (Buck et al. 2015). Alternatives considered were laminating, nailing, stapling, screwing, stress laminating, doweling, dovetailing and wood welding. CLT elements are prefabricated with high precision in modern factory settings. Several advantages are associated with such prefabrication of CLT (Smith et al. 2017). Less material waste on the building site, element accuracy due to prefabrication, reduced on-site construction time and usage of lower quality timber in structural elements are among them. CLT consist of multi-layered panels made of construction timber (Buck et al. 2015). The layers 
are arranged with the fibers perpendicular to the neighboring layer and glued together. Norwegian spruce is currently the softwood species primarily used for CLT (Brandner et al. 2016). The cross-layered structure of CLT gives a better load bearing capacity in more in more than one direction.

The ideas of Lean Production were originally developed by the Japanese car industry (Womack et al. 1990), (Howell 1999). The main concept of Lean are as follows: minimizing waste, customer orientation, product quality excellence, continuous improvement, reducing costs and flow among other elements (Howell 1999). Lean Construction is the construction industry`s adaption of Lean Production (Green 2011). "Construction is complex production of a one-of-a-kind product undertaken mainly at the delivery point by cooperation within a multi-skilled ad-hoc team" (Bertelsen and Koskela 2004). This unique product necessitates integration of the design and production processes.

The Last Planner System (LPS) is a Lean tools that has become popular in the construction business in Norway (Kalsaas et al. 2014), (Engebø et al. 2017). Norwegian companies often adopt the LPS and create their own adaption to fit LPS into their organizations. Veidekke has an adaption called Collaborative Planning (CP). They use it in all stages of the construction and in collaboration with the sub-contractors.

LPS has two main advantages in the design phase (Koskela et al. 1997). The design phase is made transparent while the design team are influencing, and are held more accountable for, the planning of their own work and deliveries. Activity becomes measurable for the design team. The other advantage is that goals and milestones are easier to set and measure against during the process. "The LPS has its main focus on the planning process (how to plan)" (Bølviken et al. 2015). Several planning concepts also focus on the content of the plan, such as Takt Planning. In construction, Takt Planning is a method for structuring the work to be done during production (Frandson et al. 2014).

A pilot project in Sundsvall, Sweden, identified that the lack of knowledge regarding the use of mass timber in multi-story buildings was source of resistance from subcontractors (Sardén 2005). The project "was a typical, transformation focused, construction project" (Sardén 2005). The study concluded, among other things, that future mass timber project should have a Lean Construction approach and that the project manager should focus more on customer value and flow during the construction process.

Veidekke has recently constructed a large-scale student housing project, located in Trondheim, using CLT and Takt Planning (Vatne and Drevland 2016). Even though it was the first mass timber project for most of the involved parties, the main contractor found that productivity increased. Better logistics and the repetitive work were believed to be the critical success factors, when compared to the traditional production planning.

In a case study in the US, seven mass timber projects of different sizes and scopes were compared to reference projects (Smith et al. 2017). On average, the total costs for mass timber projects were $4,2 \%$ lower than the corresponding buildings, mainly in concrete. Of those seven projects, four were considered to be pilot projects. One of the most important findings was that repetition of similar projects provided improved 
productivity and cost control for the contractors. Another study compared the costs of alternative load bearing structures to concrete for an art center (Mallo and Espinoza 2016). The results showed that in that specific case, the cost for a load bearing system in concrete could be reduced by $21 \%$ if most of the structure were replaced by mass timber.

On average, it was found that the reduction in overall construction time was approximately $20 \%$ in the mass timber projects (Smith et al. 2017). This reduction was primarily due to the level of prefabrication of the CLT elements and a decrease in the amount of work on site. A Norwegian study found that on-site assembly was 30-40\% faster for CLT elements than the typical schedule for producing the load bearing structure in concrete and steel (Finstad 2014).

Few studies have had an opportunity to compare these two construction methods using such similar surroundings as was available for this case project. By reducing other variables, we identify what differences there are between the two approaches to fill in the knowledge gap regarding these methods.

\section{METHODOLOGY}

This study started with a literature review and continued by conducting case-specific observation, interviews, and document studies. The initial literature review was on the topic "mass timber". The aim was to map the state of the art from a project management point of view in relation to construction in mass timber. A scoping study approach (Arksey and O'Malley 2005) was used to gradually focus the review from a general scope onto previous comparison studies between mass timber and other traditional materials.

The case is an ongoing project in Trondheim, Norway. Two apartment buildings at the same construction site were studied. One building (building A) has 5 floors. It is constructed in concrete and steel, as load bearing structure. The second building (building B) has 8 floors. It is constructed in mass timber, mainly in CLT. The footprints of buildings $\mathrm{A}$ and $\mathrm{B}$ are equal, and the floorplans are approximately the same. The two buildings were designed and are being constructed by the same main contractor, Veidekke, and with the same group of sub-contractors. A previous construction phase at the site (building $\mathrm{C}$ ) was used as a reference for building $\mathrm{A}$ and $\mathrm{B}$ for the concept development. Building $\mathrm{C}$ has approximately the same gross floor area and specifications as buildings $\mathrm{A}$ and $\mathrm{B}$.

A case study method described in (Yin 1994) was used. The strength of a case study is the variation of sources of data (Yin 1994). Documenting an ongoing case such as this building project creates unique opportunities for comparison. The ongoing project provided several opportunities for collection of different types of data in a comparable setting. In this case study, three sources of data were used. A triangulation of the data from multiple sources strengthens the validity of the results (Denzin 2012). In addition, the main author had a summer internship at the case project and is now employed as a trainee in Veidekke. The $2^{\text {nd }}$ author was a special advisor at the project. This insider knowledge provided access to documents as well as an understanding of who to interview. 
Three direct observations were conducted in design meetings. A role as a participating, but passive, observer was used as described in (Gold 1958).

As the primary source for qualitative data, five respondents from the main contractor and seven respondents from the sub-contractors, were interviewed. The interviews were semi-structured. The respondents from the primary contractor were as follows: two project developers, the project manager, the design manager and the construction manager. From the sub-contractors, the architect, the fire and acoustics consultants, and the electrical, plumbing and ventilation engineers were interviewed. The interviews were recorded and transcribed to minimize sources of error. The data from the interviews were then put in the context of the findings the study of project documents and direct observations. The document study was based on the available and relevant documents in the online project hotel of the main contractor. Economic overviews and production schedules among others were compared for the two buildings.

Since the project was still ongoing, some limitations were present. Some of the documents studied and economic overviews are not entirely complete. Regarding the production, the study is limited to what is planned. Different contract agreements made some economic comparisons difficult. The scope of the study is also limited to the most essential consultants and sub-contractors in addition to the main contractor.

\section{RESULTS AND DISCUSSION}

\section{DIFFERENCES IN CONCEPT DEVELOPMENT AND DETAILED DESIGN}

In this case, the buildings are constructed over a shared parking garage located in the basement. The structural engineer estimated that it took triple the time to complete the design of the concrete ground floor in building B than for building A, primarily because the CLT elements lacked the ability to distribute the vertical loads horizontally in the load bearing walls. This characteristic of CLT resulted in the need to add large concrete beams under the ground floor. In addition, the CLT-elements needed to be anchored to the concrete slab at the ground floor. Over one hundred steel plates for anchoring had to be modelled and drawn in separate drawings and cast into the concrete slab. For contractors who want to benefit from the advantages of CLT, an optimized basement design is feasible. However, a way to acquire knowledge on new materials is by conducting pilot projects. The large beams became an unexpected challenge for the technical infrastructure in the basement and led to extra design work.

The difference between the time and design required for building B versus A seems to be a direct effect of the use of mass timber in building B. An alternative use of the basement space may have made this difference smaller. Optimizing the basement for mass timber could potentially eliminate most of the extra challenges experienced in this project.

The two main issues influencing both design and planned production evidently were fire and acoustic-related challenges. The timber material is flammable, while concrete is not. This difference results in stricter requirements for fire engineering in Norway for CLT construction. A combination of limited knowledge and a lack of available pre- 
accepted solutions for CLT construction in apartment buildings, developing techniques to accommodate CLT has provided challenges and required extra time of the fire consultant during concept development and detailed design. Once standard approaches are developed using CLT, the need for extra time to develop fire-related solutions is likely to decrease.

The reduced internal mass of the building when switching from concrete to CLT has also posed acoustic challenges. Noise reduction requirements between apartments are the same regardless of the materials used. The lack of construction approaches for buildings using CLT was evident during the design phase. The acoustic consultant estimated an increase of up to $100 \%$ more time spent to develop details for building B than usual.

The architect and the main contractor emphasized the combined effect of the fire and acoustic challenges. Because both had limited experience with CLT in apartment buildings, their engineered solutions were cautious to make sure the requirements are met. As a result, construction details were developed that made the planning of the furnishing work by the order of the work packages more complicated in the takt plan. Hence, the takt plan was different for the two buildings. The same crew was planned to work through both buildings in a takt train. The new solutions and details necessitated a second takt plan with more work packages. It also lead to a significant increase in the assembly of fire plasterboards compared to the concrete counterpart, requiring a greater proportion of simple assembly work planned for building B compared to building A.

In traditional concrete buildings, the concrete walls often have the same dimensions on all floors. In the mass timber building, the dimensions of the CLT elements decrease up through the floors. This difference has led to increased work for several parties during detailed design. The apartments, which essentially should be equal, have some variations due to the CLT-elements.

The possibility for labour saving copying of work in the BIM-model decreases when the dimensions are changing. This variation has led to more time spent to adjust the BIMmodel for building B. It was an effect that was hard to mitigate when the main contractor also wanted to limit the CLT-volume to reduce costs. In building A, more copying was possible, placing a greater burden on the architect for building B. In addition, the electrical engineer expressed inconvenience for placing of electrical components in the BIM-model.

The main contractor expected improved HSE for the mass timber building. Previous experience from a student housing project using CLT by the main contractor Veidekke indicated significantly improved noise and dust conditions.

These factors are believed to generate improved productivity and earnings for the contractor in the short term but can also be significant for the long term. Worker health is important to any contractor to maintain productivity rates long term.

In general, all the respondents expressed an increased level of uncertainty related to the mass timber building, mostly related to the lack of experience and pre-developed solutions. The respondents had experienced this kind of uncertainty previously when new construction methods and materials were introduced. Some of the parties had taken 
precautions and expected greater time consumption in the design phase but unexpected challenges occurred. Most of them were believed solved during concept development but had to be revised during the detailed design phase. In addition, the architect was assigned several unexpected tasks. This type of uncertainty seems not to be unique for mass timber projects but instead can be expected when other new materials and methods are introduced.

Involvement in the concept development in this project was more extensive than usual both a measure for risk control and because the main contractor needed to develop new construction details for the CLT option. The main contractor also engaged one additional in-house resource with experience on CLT during the development phase.

Both the concept development and the detailed design were carried out using the same methodical approach, CP. Early involvement through CP may have lowered the perception of risk concerning building B. Also, the early development of many of the main features of building B seem to have positively affected the perception of risk in the project.

All the respondents concur and were satisfied with the implementation of the design process. The main difference for them was an increased number of special design meetings. Held in addition to the main design meetings, these meetings were where special topics were worked through by the relevant parties. Since the process was common for both buildings, some conflicts occurred. Challenges in one building influenced the progress of the other. These delays affected both buildings, but the respondents felt it was most problematic when the concrete building influenced the mass timber building, especially because the level of uncertainty was higher concerning the CLT.

Observations also confirmed that up to $2 / 3$ of the time in the design meetings was used for building B, possibly resulting in some level of neglect for building A. Overall. the process with $\mathrm{CP}$ seemed to result in a relative smoothly implementation of both phases.

The total construction time from the ground floor to move-in ready for building $B$ were scheduled for 38 weeks and for building A, 42 weeks. The assembly of the CLT elements was scheduled at 8 weeks for building B. The construction of the concrete and steel was scheduled to take 13 weeks for building A. The detailed design period was the same for the two buildings since it was one common process and consisted of 13 design meetings over a period of 26 weeks. The furnishing phase, however, was scheduled for 19 weeks for each floor in building A and for 23 weeks in building B. Even though the furnishing phase had a longer duration, the CLT was advantageous when it came to total construction time when taken in to consideration that building A is 5 floor and B, 8 floors.

Some cooperation issues occurred during the detailed design phase. The structural engineer for the mass timber was not present in any of the design meetings. Several in the design team pointed this out as problematic, especially the architect, who usually cooperates closely with the structural engineer, found it difficult to facilitate the cooperation. Feedback was also late, which on several occasions resulted in having to 
redraw, thereby slowing down the design process for the architect and sub-contractors. In hindsight, the CP could have been stricter on committing the structural engineer.

The observations confirmed several obstacles for good flow in design meetings caused by the mentioned issue. To get a good flow through the design process the main contractor depends on reliable consultants and sub-contractors. The issue had also been experienced in other projects by the respondents.

A general challenge in projects is builder choices. In this case, limitations created by early decisions from the builder also created constraints, complicating the development of solutions and construction details. Such challenges also occur when using traditional concrete, but the implications are greater when new main materials are introduced.

The mass timber contractor was a turnkey contractor, who delivered and assembled the CLT elements. For the concrete counterpart, the main contractor performed the load bearing structure construction. This difference led to a loss of own value creation for the main contractor. If the contractors were to acquire the assembly skills, this loss could be reduced or eliminated.

\section{COST DIFFERENCES IN CONCEPT DEVELOPMENT AND DETAILED DESIGN}

The case project had 7\% higher total cost during concept development than building $\mathrm{C}$, mainly due to a higher architect cost. The builder was surprised it was not more significant difference. For building $\mathrm{C}$, it had been necessary to redraw the floorplans to accommodate the housing market, leading to higher costs. The case project was built on sensitive clay and it is worth mentioning that there was a $50 \%$ reduction in the costs for geotechnical consultants in the case project compaired to building $\mathrm{C}$. The reduced weight of building B was the main reason for the savings. For building A and B, costs for the architect, fire and acoustic consultants, and the structural engineer were different. The cost differences for the structural engineering, fire consultant and acoustic consultant in the concept development are shown in table 1. Other consultant costs were approximately the same.

Table 1- Key figures, cost data from the concept development

\begin{tabular}{lcc}
\hline & Costs for concept development (NOK): \\
\hline & Building A & Building B \\
Structural engineer & $80^{\prime}$ & $165^{\prime}$ \\
Fire consultant & $42^{\prime}$ & $260^{\prime}$ \\
Acoustic consultant & $42^{\prime}$ & $46^{\prime}$ \\
\hline
\end{tabular}

During detailed design, mainly the costs for the architect, fire and acoustic consultants, and the structural engineer were greater for building $\mathrm{B}$. Other consultant costs were similar during concept development phase: when adjusted for gross floor area.

Table 2- Key figures, cost data from the detailed design

\begin{tabular}{lcl}
\hline & Costs for detailed design $\left(\mathrm{NOK} / \mathbf{m}^{2}\right)$ : \\
\hline & Building A & Building B \\
Architect & 218 & 260
\end{tabular}




\begin{tabular}{lll} 
Structural engineer & 95 & 101 \\
Fire consultant & 21 & 42 \\
Acoustic consultant & 32 & 55 \\
\hline
\end{tabular}

These increased costs during concept development and detailed design were with great certainty mostly attributable to the use of mass timber. The main contractor likely will be able to reduce these if more buildings were to be constructed using CLT in the future.

\section{CONCLUSIONS}

The objective of this study was to investigate how lean measures like Last Planner and Takt influence the construction process when new and green materials are introduced. To answer this objective, three research questions were formulated:

- What are the differences between construction in cross laminated timber (CLT) and on-site cast concrete?

- What pros and cons are associated with the use of CLT?

- How can contractors improve construction with CLT?

Three categories of differences between construction in CLT and on-site cast concrete were identified by the respondents in this study, listed in Table 3.

Table 3- Experienced differences when constructing in CLT versus cast concrete

\begin{tabular}{lll}
\hline Due to mass timber: & $\begin{array}{l}\text { Due to new material, not mass } \\
\text { timber explicitly: }\end{array}$ & $\begin{array}{l}\text { Occurring in any type of } \\
\text { project: }\end{array}$ \\
\hline $\begin{array}{l}\text { Enlarged concrete } \\
\text { beams in the basement }\end{array}$ & $\begin{array}{l}\text { Level of uncertainty in concept } \\
\text { development and detailed design }\end{array}$ & Cooperation issues \\
\hline $\begin{array}{l}\text { Development of } \\
\text { acoustic solutions }\end{array}$ & $\begin{array}{l}\text { Development of new construction } \\
\text { details }\end{array}$ & Builder choices \\
\hline $\begin{array}{l}\text { Development of fire } \\
\text { solutions }\end{array}$ & $\begin{array}{l}\text { Early involvement of sub-contractors } \\
\text { and consultants using CP }\end{array}$ & $\begin{array}{l}\text { Decreased value creation } \\
\text { for the main contractor }\end{array}$ \\
\hline $\begin{array}{l}\text { Dimensions of CLT- } \\
\text { elements }\end{array}$ & Implementation of the design process & \\
\hline $\begin{array}{l}\text { Improved HSE during } \\
\text { production }\end{array}$ & Shortened construction time & \\
\hline
\end{tabular}

Acoustic, fire and structural challenges related to the use of CLT caused extra work during concept development and detailed design. The architect and the main contractor were the most influenced parties. The costs for building B can most likely be reduced if the main contractor reuses the developed solutions in future projects.

The CLT-elements represent an advantageous construction method. Reduced construction time and the accuracy of the elements due to prefabrication are the most significant benefits. Reduced material waste at the building site, improved HSE and reduced $\mathrm{CO}_{2}$ emissions are among the sustainability benefits for contractors. The main drawbacks with CLT in this case is the loss of work that can be carried out with in-house capacity and an increased design cost. Production costs were not included in this study.

When it comes to how contractors can improve construction with CLT, Lean tools such as Last Planner and Takt proved advantageous in the studied pilot project. With 
higher uncertainty arises the need for increased planning for the unforeseen. These tools provided the stability needed for tackling the uncertainty that entailed the introduction of a new and green material as CLT. Early involvement through CP may have lowered the sub-contractor's perception of risk concerning building B. To get a good flow through the design process, the main contractor depended on reliable consultants and sub-contractors. $\mathrm{CP}$ and Takt can be used to secure this reliability, and these tools may have influenced the outcome more than the respondents have realized so far.

\section{REFERENCES}

Arksey, H., and O'Malley, L. (2005). "Scoping studies: towards a methodological framework." International Journal of Social Research Methodology, 8(1), 19-32.

Bertelsen, S., and Koskela, L. u. (2004). "Construction Beyond Lean: A New Understanding of Construction Management." Proc., 12th Annual Conference of the International Group for Lean ConstructionHelsingør, Denmark.

Brandner, R., Flatscher, G., Ringhofer, A., Schickhofer, G., and Thiel, A. (2016). "Cross laminated timber (CLT): overview and development." European Journal of Wood and Wood Products, 74(3), 331-351.

Buck, D., Wang, X., Hagman, O., and Gustafsson, A. (2015). "Comparison of different assembling techniques regarding cost, durability, and ecology - a survey of multilayer wooden panel assembly load-bearing construction elements." BioResources, 10(4), 8378-8396.

Bølviken, T., Aslesen, S., and Koskela, L. (2015). "What Is a Good Plan?" Proc., 23rd Annual Conference of the International Group for Lean ConstructionPerth, Australia, 93-102.

Denzin, N. K. (2012). "Triangulation 2.0." Journal of Mixed Methods Research, 6(2), 8088.

Engebø, A., Drevland, F., Lohne, J., Shkmot, N., and Lædre, O. (2017). "Geographical Distribution of Interest and Publications on Lean Construction." Proc., 25th Annual Conference of the International Group for Lean ConstructionHeraklion, Greece, 285-292.

Finstad, T. (2014). "Økonomisk Lønnsomhet ved bruk av bæresystemer i massivtre." Master thesis, Norwegian University of Life Sciences.

Frandson, A., Berghede, K., and Tommelein, I. D. (2014). "Takt-Time Planning and the Last Planner." Proc., 22nd Annual Conference of the International Group for Lean ConstructionOslo, Norway, 571-580.

Gold, R. L. (1958). "Roles in Sociological Field Observations." Social Forces, 36(3), 217-223.

Green, S. D. (2011). Lean Construction, Oxford, UK: Wiley - Blackwell, Oxford, UK.

Howell, G. A. "What Is Lean Construction - 1999." Proc., 7th Annual Conference of the International Group for Lean ConstructionBerkeley, USA.

IPCC (2014). "Climate Change 2014: Mitigation of Climate Change." Contribution of Working Group III to the Fifth Assessment Report og the Intergovernmental Panel on Climate Change, O. Edenhofer, R. Pichs-Madruga, Y. Sokona, E. Farahani, S. 
Kadner, K. Seyboth, A. Adler, I. Baum, S. Brunner, P. Eickemeier, B. Kriemann, J. Savolainen, S. Schlömer, C. von Stechow, T. Zwickel, and J. C. Minz, eds., Cambridge University Press, Cambridge, United Kingdom.

Kalsaas, B. T., Grindheim, I., and Læknes, N. (2014). "Integrated Planning vs. Last Planner System." Proc., 22nd Annual Conference of the International Group for Lean ConstructionOslo, Norway, 639-650.

Koskela, L., Ballard, G., and Tanhuanpää, V.-P. (1997). "Towards Lean Design Management." Proc., 5th Annual Conference of the International Group for Lean ConstructionGold Coast, Australia.

Mallo, M. F. L., and Espinoza, O. (2016). "Cross-laminated Timber vs. Concrete/Steel: Cost comparison Using a Case Study." 2016 World Conference on Timber Engineering, Vienna University of Technology, Vienna, Austria.

Petersen, A. K., and Solberg, B. (2005). "Environmental and economic impacts of substitution between wood products and alternative materials." Forest Policy and Economics, 7(3), 249-259.

Sardén, Y. (2005). "Complexity and learning in timber frame housing: the case of a solid wood pilot project." Doctoral thesis, Luleå University of Technology.

Skullestad, J. L., Bohne, R. A., and Lohne, J. (2016). "High-rise Timber Buildings as a Climate Change Mitigation Measure - A Comparative LCA of Structural System Alternatives." Energy Procedia, 96, 112-123.

Smith, R. E., Griffin, G., Rice, T., and Hagehofer-Daniell, B. (2017). "Mass timber: evaluating construction performance." Architectural Engineering and Design Management, 1-12.

Vatne, M. E., and Drevland, F. (2016) "Practical Benefits of Using Takt Time Planning: A Case Study." Proc., 24th Annual Conference of the International Group for Lean ConstructionBoston, USA.

Womack, J. P., Jones, D. T., Roos, D., and Technology, M. I. o. (1990). Machine that Changed the World, Scribner.

Yin, R. K. (1994). Case study research:design and methods, Sage, Thousand Oaks, Calif. 